TERAKREDITASI Berdasarkan SK Dirjen Dikti Depdiknas Nomor: 65a/DIKTl/Kep/2008

MENIMBANG KOMPATIBELITAS MULTIKULTURALISME DAN ISLAM: IKHTIAR MENGGAGAS PENDIDIKAN ISLAM MULTIKULTURAL DI INDONESIA Mukhlis

ASESMEN AKHLAK MULIA: Suatu Model Alternatif Penilaian Pembelajaran Agama Siti Muri'ah

MENILAI Ulang GAGASAN NEGARA KHILÂFAH ABÛ AL-A'LÂ AL-MAUDÛDî Arsyad Sobby Kesuma

AL-A'IMMAH MIN QURAISY: ANTARA DOKTRIN DAN KEBUTUHAN SOSIAL Ahwan Mukarrom

SISTEM KALENDER ISLAM DALAM PERSPEKTIF EVOLUSI SYARI'AA Abd. Salam

Desain DakWAH untuk PEMBINAan KeAgamaAn KOMUNITAS ELIT INTELEKTUAL Bukhari 


\section{PEDOMAN TRANSLITERASI}

\begin{tabular}{|c|c|c|c|}
\hline Arab & Latin & Arab & Latin \\
\hline 1 & $=$ & ف & $=\mathbf{f}$ \\
\hline ب & $=$ & ق & $=\mathrm{q}$ \\
\hline$\dot{H}$ & ts & ك & $=\mathrm{k}$ \\
\hline 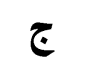 & $=$ & J & $=1$ \\
\hline$\tau$ & $=$ & r & $=\mathrm{m}$ \\
\hline$\dot{\tau}$ & $=\mathbf{k h}$ & ن & $=\mathbf{n}$ \\
\hline$د$ & $=$ & و & $=\mathbf{w}$ \\
\hline$\dot{j}$ & $\mathrm{dz}$ & ○ & $=h$ \\
\hline J & $=$ & $\varepsilon$ & $=$, \\
\hline j & $=$ & ي & $=\mathbf{y}$ \\
\hline س & $=$ & & \\
\hline ص ش & $\begin{array}{l}\text { sy } \\
\text { sh }\end{array}$ & \multicolumn{2}{|c|}{$\begin{array}{l}\text { Untuk Madd } \\
\text { dan Diftong }\end{array}$} \\
\hline ض & $=$ & $i=$ & $=\hat{a}$ (a panjang) \\
\hline$b$ & th & إين & $=\hat{\mathbf{i}}(\mathbf{i}$ panjang) \\
\hline ظ & $\mathbf{z h}$ & أوز & $=\hat{\mathbf{u}}$ (u panjang) \\
\hline$\varepsilon$ & $=$ & آوز & $=$ aw \\
\hline$\dot{\varepsilon}$ & $=\mathbf{g h}$ & = آين & $=$ ay \\
\hline
\end{tabular}




\section{ISI}

TRANSLITERASI

ARTIKEL

Mukhlis

Menimbang Kompatibelitas

Multikulturalisme dan Islam:

Ikhtiar Menggagas Pendidikan Islam

Multikultural di Indonesia • 201-224

Siti Muri'ah

Asesmen Akhlak Mulia:

Suatu Model Alternatif Penilaian

Pembelajaran Agama • 225-248

Yusuf Hanafi

Perkawinan Anak di Bawah Umur

dalam Perspektif Hukum Islam • 249-274

Arsyad Sobby Kesuma Menilai Ulang Gagasan Negara Khilâfah

Abû al-A'lâ al-Maudûdî • 275-300

Ahwan Mukarrom Al-A'immah min Quraisy:

Antara Doktrin dan Kebutuhan

Sosial • 301-322

Abd. Salam

Sistem Kalender Islam dalam Perspektif

Evolusi Syari'ah • 323-350

Bukhari

Desain Dakwah untuk Pembinaan

Keagamaan Komunitas

Elit Intelektual • 351-370

Ahmad Munir Teologi Properti:

Telaah Eksistensi dan Fungsi

Kekayaan • 371-392

BOOK REVIEW

Ahmad Fathan Aniq Discovering Indonesian Islam through Fatâwâ • 393-408

INDEKS 


\title{
DISCOVERING INDONESIAN ISLAM THROUGH FATÂWÂ
}

\author{
Ahmad Fathan Aniq*
}

Title: Indonesian Islam: Social Change through

Contermporary Fatâwâ

Outhor: M. B. Hooker

Publisher: Crows Nest, NSW: Allen and Unwin;

Honolulu: University of Hawaii Press, 2003

Thickness: 310

In the field of Indonesian-Islam studies, Hooker's 'Indonesian Islam' is a welcome contribution to the scholarship. Unlike other Western scholars who study Indonesian Islam through anthropology, Hooker through his publication tries to show us that Islam in contemporary Indonesia can be known from fatâwa (pl. fatwa) that have been responding matters of Indonesian Muslim society, have colored them and have been followed by them. For this reason, Hooker chooses four main Indonesian fatwa-issuing institutions which have been responding to challenges of modernity. They are Persatuan Islam (Persis), Muhammadiyah, Nahdlatul Ulama (NU) and Majelis Ulama Indonesia (MUI) and further, they are called "sources" or sources of fatâwâ. As a focus of the study, Hooker takes the fatâwa from 1920s to the 1990s, from the period of colonialism to independence, which encompass the vast political, social and legal changes of this period. (p. iix)

*Penulis adalah dosen Institut Agama Islam Negeri (IAIN) Sunan Ampel, Jln. A. Yani 117 Surabaya. e-mail: fathananiq@gmail.com 
Hooker views that the fatâwa are very important because they are internal responses to issues which are faced by the umma. The issues in this sense are seen by them as vital for truly performing the duties that all Muslims owe to God. Nowadays, in the beginning of the $21^{\text {st }}$ century, Indonesian state claims to have authority in determining how Islam should be in Indonesia. However, the fatâwa seems to re-affirm that authority is in God and 1400 years of intellectual tradition is primary. The possibility of these two authorities to be in opposite positions and more usually they shade or merge into each other is therefore the thesis of this book. (p. ix) Furthermore, to him only the fatâwa can tell us what Islam is in Indonesian context. While Islam is immutable in theory, it is variable in practices, as the book demonstrates.

\section{Content Analysis}

The introduction of the book aims at providing materials which are necessary to understand the Indonesian fatâwa at the end of the $20^{\text {th }}$ century. Hooker starts the introduction by presenting definition(s) of fatwa, requirements to be a mufti, and a short historical context of how fatwa was originated. In addition, before he really talks about Indonesian context of fatâwa he shows readers the new scholasticism in the Arabic world, especially in Egypt. By showing how Islam is understood there, the author wants to argue that it is a common misconception to suppose that Islamic reform in Indonesia is little more than a rerun of Egyptian intellectualism. To him, the facts of Indonesian Islamic life are different from those of the Arabic Middle East. Islam in Indonesia has its own complexities which are formed by at least three factors: the indigenous Islam, Islam in the era of the Netherlands East Indies, and the postindependence Islam.

The indigenous Islam is Islam which has acculturated with local wisdom or local custom. We can find many materials 
which indicate the acculturation such as Serat Cebolek, Serat Centini, Suluk Wujil, Serat Yusuf and even some texts of translation from Arabic figh books in which elements of the fiqh were incorporated in local rules. They are not adaptations or copies of the Arabic, instead, they are original works expressing a local understanding of Islam.

Indonesian Islam experienced also the Netherlands East Indies' rules. At that time, Islamic law in colonial Indonesia was limited to marriage, divorce and inheritance which can be understood only as an aspect of colonial politics. As stated by Hooker, the 1920s and 1930s were a period of increasing anticolonial agitation that much of it had a strong Muslim element. It was the colonial response to this agitation which determined the nature of Islamic legal jurisdiction. Therefore, religion was bound up with politics and, as the law was an integral part of religion, its substance and application were equally political in nature. (p. 14)

In the post independence, Islam has been in a direct place in the new politics of independence, and this place of Islam has remained at the centre of Indonesian politics for the last halfcentury. In this period, Indonesia was in search of its constitution whether it would be based on Islamic constitution such as reflected in the Jakarta Charter or not. Finally, even though it is not Islamic state, Indonesia remains a religious state by mentioning God in the exalted position such as reflected in the preamble of the constitution, "Belief in One Supreme God". The implication of this first principle of Pancasila is the establishment of a Ministry of Religious Affairs which its main functions, according to Hooker, are political - to promote religion generally and Islam in national politic particularly. (pp. 19-20)

However, Hooker leaves a very important thing that makes Indonesian Islam different from others. It is the internal Islamic jurisprudence that provides a big opportunity for Muslims in 
certain place to accommodate local customs into their religion. The example for this is a qa'idah fiqhiyyah: "al- adab mubakkamab" which means the custom can be used for laws.

According to Hooker, the three factors that form Indonesian Islam can be well understood from the scholasticism of the $20^{\text {th }}$ century in Indonesia. Furthermore, the Indonesian scholasticism can be divided into a responsive scholasticism and a creative scholasticism. The first is found in the colonial period and is characterized by a defensiveness in law and dogma. They went into defending and demonstrating the perfectness of Islam in the face of the obvious fact of its subject status in colonial NEI. The second is those who are self-confident enough to propose serious change, alternation and adaptation of classic scholasticism. People such as Hazairin, Munawir Sjadzali, Harun Nasution, Nurcholis Madjid and Abdurrahman Wahid have a common intention to explain the truth of Islam from within in a way that is positive and useful for the Indonesian ummat even though they were/are often criticized. (p. 45)

In the first chapter - "Knowing Islam: method, doctrine and representation"- Hooker talks about fatâwâ which show us three ways in which we can know Islam in Indonesia. The first is various methods of reasoning. The second is written doctrines, and the third is the representation of Islam. These three aspects of knowing are extensively discussed in the fatâwa are taken together, they give us a preliminary answer to know Islam in Indonesia.

In this chapter, the author explains general methods of how the four sources arrive at a result or a fatwa. The Persis's fatâwa largely, though not entirely, are the work of one man, Ahmad Hasan (1887-1958). His literal fatâwâ are resulted from his reading method, which consist of the Qur'an (basic source), language and hadits. (p. 48) The linguistic section is the areas in which disputation usually occurs. Persis by no means rejects ijmâ'. To them, ijmấ is of man and can never form a part of the 
laws of God. Allah did not command us to follow ijmâ' which was made by a crowd of ulama. (p. 52)

Like Persis, Muhammadiyah finds its Islam in ijtihad but it understands the concept in a quite different way. The major method used is employing reason, but in accordance with the teachings of Islam. However, the exercise of reason, ijtihad, is limited by the sources - the Qur'an and the Sunna-and to techniques of analysis already known in the fiqh literature such as

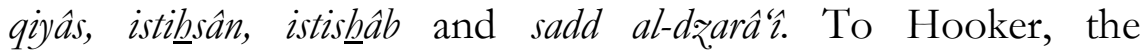
implications of the Muhammadiyah method of ijtihad brings about inconsistency. For example, the simultaneous use of qiyâs, istishlâh and istis $\underline{b} \hat{b}$ has involved the Majlis Tarjih in talfiq $q$, where there is an acceptance and rejection of principles from Hanbali, Shafi'i and Hanafi in the same fatwa. (p.55)

NU has another way of issuing fatâwâ. It has been searching the ideal method since its establishment until nowadays. Formerly, NU set out a hierarchy of sources for issuing fatâwâ. Ulama of NU arranged the sources from within shafi'ite-mazhab books. Thus, the referring to fiqh book is usually called taqlid. Other groups, even NU members themselves, call NU as doing taqlid to get fatwa. However, Hooker rather disagrees if this term is stuck to NU's activity in issuing fatâwâ. (p. 56) As the book shows, what NU has been done is exercising ijtihad rather than taqlid. For this, Hosen prefers to state that theoretically, the NU stands in a position somewhere between ijtihad and taqlìd. ${ }^{1}$

MUI's method is an interesting phenomenon since its members are composed of many groups. To Hooker, this leads to eclecticism in determining methods and sources of authority. (p. 61) Further, Hosen states that the formulation of MUI's method was influenced by both NU and Muhammadiyah. ${ }^{2}$

${ }^{1}$ Nadirsyah Hosen, NU \& Collective Ijtihad, New Zealand, Journal of Asian Studies 6, 2004, p. 11

${ }^{2}$ Nadirsyah Hosen, Fatwas of Majelis Ulama Indonesia, Journal of Islamic Studies 15:2, 2004, p. 153 
There are other institutions and individuals which issued fatâwâ such as the Ministry of Health, al-Jam'iyatul Washiliyah and Dewan Dakwah. However, from these institutions, Hooker only mentions the fatâwa of the Ministry of Health. Furthermore, he does not discuss one person's fatwa.

"Doctrine" is another way to know Islam which is frequently found in fatâwâ. Even though Islam is originated from Arabia, it is a universalistic theology and its perceived purity of doctrine is crucial whatever the time, place and circumstance. Such a kind of doctrine can easily be found in Indonesian fatâwa . From the sources, Hooker mentions some examples of how Indonesian ulama maintain their religion from the impurity of doctrine. How Muslims deal with Christians and their ceremonies has become hot issues in Indonesian religious lives. Furthermore, the Ahmadiyah Qodiani and the Darul Arqam are sects which have been prohibited in Indonesia. However, Hooker sees that the MUI's fatwa on the later sect, like in Malaysia, is very political. It is seemingly a worry of the state on a successful alternative which was both economic and personal neo-Sufism.

The third way to know Islam according to Hooker is from the representation of Islam. There is a necessity to control image and image-making in Islam. However, what are the permissible limits for representations in Indonesian Islam? The author mentions some fatâwâ regarding this issue. Nevertheless, the fatâwa which are found and are mentioned are entirely old fatâwâ. Therefore, in my opinion, it is meaningless to look at Islam from this perspective nowadays.

The second chapter covers individual and religious duties which are related to the five pillars of Islam. In the last of the first chapter, Hooker states that the fatâwa seem to demonstrate that permissible (mubah) has now become highly charged and as stated by him, the intention of the second chapter is to try to give some meanings to "highly charged" by taking fatâwâ on the five pillars. (p. 88) Furthermore, he argues that an individual 
Indonesian Muslim in 2001 is in an extremely difficult position. The state nowadays controls religious practices including the most personal obligations such as to perform one's obligation in prayer. (p. 121) However, this statement can be criticized as to what extent does the state intervene on the religious matters?

Hooker claims that fatâwâ, especially which are issued by MUI, on how, when and where one should perform prayer (shalat) perhaps can be seen as the state intervention. (p.90) If this is what he means by the state intervention, of course this is too exaggerated. To my view, the state can be called intervening religious matter, such as in prayer, if the state commands everyone to pray and punishes that who leaves it. MUI's or other institutions' fatâwâ on how one should perform prayer is only religious guidance which is not binding and thus it is not a kind of state intervention on personal obligations. Matters of capitalization of money in rakat (p.114) and times, funding and travel of pilgrimage (haj) (pp.117-121) are other examples which are given by Hooker as to how the state successfully insists on its own position on religious matters. By these examples, he emphasizes that there is a tension between Revelation and the state. Each has its own source of legitimacy, from God or from the constitution. (p. 121)

In chapter three, Hooker looks at status and obligation of women. These can be seen from prescriptions that set out personal status based on gender and the attribution of duties appropriate to the status. He uses "prescription" rather than "rule" to avoid confusion with judicial decisions. To Hooker, there are four sources of prescription for Indonesian Muslim

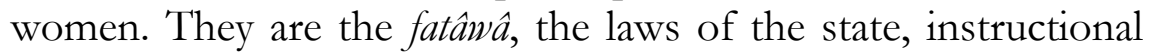
literature, and the Friday sermon (khutbah). (p. 122) The last three, however, have something to do with the fatâwâ. For example, the instructional literature (panduan) and the Friday sermon seem to be like a fatâwâ giving about how Muslim women should be. 
Regarding the laws of the state, the prescription of women seems problematic since the syariab is now a part of the positive law of the Indonesian state. There are two laws which must be noticed together by Muslim women. They are the Compilation of Islamic Law (1991) and the Marriage Law (1974). (p. 123) Hooker sees that this matter is so problematic and imprecise because he looks at it from a very secular point of view. For example in the case of marriage, since a marriage in Indonesia must be registered and a non-registered marriage means unlawfulness, he suggests that the marriage should not be regulated by the state, since it is an individual matter.

In addition, in this chapter Hooker discusses more about the status of women as defined by the syariah. Here, he talks about head covering and clothing generally, women going out of houses, and women's authority. However, some cases which are raised by him are not followed by information of place where the cases have taken place. For example, he says, "now, in the year 2003, women go to the mosque". (p. 134). For me, this is very partial, because in some other places women have been being allowed to go to mosques either for praying or for attending other religious activities since many years ago. This is also the problem of limiting of the study on the four sources. Before the Indonesian Independence Day, the three sources, NU, Persis and Muhammadiyah, were hardly found in islands outside of Java. ${ }^{3}$

Meanwhile, Hooker smartly raise many discriminative fatâwâ such as NU's fatwa which states that women may attend the mosque depending on age, beauty, whether fashionably dressed,

${ }^{3}$ Once NU held the $11^{\text {th }}$ conference out of Java in Banjarmasin, East Kalimantan, in 1936. See the fatâwâ of this conference in Imam Ghazali Said (ed.), Abkam al-Fuqoha, Solusi Problematika Aktual Hukum Islam, Keputusan Muktamar, Munas, dan Konbes Nabdlatul Ulama (1926-1999 M.), Surabaya: LTN NU Jawa Timur, 2005, pp. 176-190 
wearing perfume or showing off. (p. 134). For me this fatwa is very discriminative and ambiguous.

As regard to marriage, the author discusses some fatâwâ such as the issue of monogamy, polygamy and polyandry, mut'a or temporary marriage, the concept of exclusion for instance "saudara susu", menstruation or haid, iddah, elopement or kawin lari, marrying a bad woman or wanita jahat, and marrying a second wife on condition that intercourse with the first wife is forbidden. However, Hooker does not mention interfaith marriage or nikah beda agama, whereas this issue also is a dominant issue in Indonesian marriage matters and we can find fatâwâ on it. ${ }^{4}$

In the fourth chapter, Hooker explores more about the relationship between Islam and medical science. Here, he makes a very provocative title, "Is God still the Creator?". At the first sight, it seems that he wants to challenge Muslim society by posing such a question. However, when we read all passages of the chapter, we will understand that what he means is whether Indonesian Muslims ignore the revelation of God in answering the medical-science questions and look at them as a value-free or not. Therefore, he elaborates many fatâwâ, including those from the Ministry of Health, and quotes many Qur'anic verses and Ahadits which are cited by the sources in order to show their position. Meanwhile, he sees that the quotations of verses which are cited by the sources are often incomplete and eclectic. To him, this is perhaps to support their arguments. (pp.169-168)

There are four main topics of this chapter. First is about general issues of Islamic views on science and medicine, including the creation of -first- man. The questions are: is Adam the first human? What is an Islamic science? Is it fine to justify the scientific inventions with religious texts such as the Qur'an? The second topic is about the prevention and denial of life. Here

${ }^{4}$ Imam Ghazali Said (ed.), ibid, pp. 433-436 
Hooker explores fatâwâ which related to contraception and abortion. Regarding the contraception, the discussion is on the subject of the birth control in the light of revelation. While, when discussing about the abortion, the questions are at what stage does life begin and who is to determine this, including determining to prevent it? The third topic is the preservation of life. Here the author discusses about invasion of the body such as autopsy, plastic surgery and sex change; transfusion and transplants; and milk banks. The last topic in this chapter is about the 'creation' of life which is through cloning.

From many fatâwâ which were discussed by Hooker, he finally comes into conclusion that God is still the creator in Indonesian Islam, because as the fatâwâ demonstrate, medical science is not value-free. The sources still highly consider ethical values in order to proceed and to judge science. Divine authority is therefore not diminished by science.

In chapter five, Hooker once more makes a provocative title, "Offence against religion". Apparently, what he means by 'offence' is every case which is non-compliance with fiqh. Therefore, the purpose of this chapter is, firstly, concerning with controversial issues in contemporary public life. The second purpose is to know how the figh classification -wajib, sunnah, mubah, makruh, haram- to be defined in the circumstances of contemporary Indonesia.

Nevertheless, I am less impressed by how Hooker arranges the subject of this chapter. Here, he writes every fatwa on cases which are not found in classical-figh books in a poorly ordered subject. For example, firstly he talks about "a fatwa on definition" which is related to an issue of whether a medical injection is permissible during Ramadhan. (pp. 195-197) After that, he talks about "money and money contracts" which is including interest-based banking and insurance. (pp. 197-211) This is related to economic issues. However, next, he talks about "food and drugs" (pp. 211-220) which are more related to the 
first issue. Furthermore, in the end he discusses about "public morality", including public massage and lotteries. (pp. 220-226) For me, the issue of lotteries has closer connection to the second subject which is about economic issues. The arrangement of the subject in this chapter tends to make readers unfocused on the passages.

Even though Hooker talks about many new issues which are non-compliance with figh, he does not mention some other current issues such as Multi Level Marketing (MLM) and the establishment of PT. Syarikat Takaful Indonesia, whereas this institution had been established in 24 February 19945, long times before Hooker's book was published in 2003. Furthermore, although in these issues Hooker frequently says that Indonesian fatâwa are inconsistent, it seems that he considers the reason. In the concluding remarks of this chapter, he states that the fatwa on issues of money, food and public morality are according to how one defines. (p. 227)

Lastly, in the epilogue, Hooker makes some conclusions of all previous chapters. The epilogue seems to be the core of the book. While in the former five chapters, Hooker exposits Indonesian fatâwâ from the sources, in the epilogue, he tries to make some patterns for an Indonesian Islam. As he states, the purpose of the epilogue itself is to indicate what the fatâwa tell us at the beginning of the $21^{\text {st }}$ century and what the issues for creativity might be. (p. 228) For these purposes, he explains some common issues of the chapters.

Firstly, he talks about authority and/or ijaza which he uses them interchangeably. (pp. 229-230) In my understanding, these two terms give a different sense in meaning. The former usually refers to the legitimacy, justification and right to exercise a power, while the later usually refers to the activity of teachers who give legality to their students to teach or to issue fatâwâ.

\section{5://www.takaful.com/index.php/profile/list/}


Therefore, it will make readers confuse when they are used interchangeably.

Dealing with references, one of authoritative factors in issuing fatâw $\hat{a}$, used by Indonesian ulama, nowadays is that they not only quote from medieval 'ulama's books but also from those written by contemporary 'ulama' such as Wahbah alZuhaili, ${ }^{6}$ Dr. M. Yusuf Musa and Dr. Abd al-Qadir Audah. ${ }^{7}$ Furthermore, some Indonesian Muslims not only quote the Middle Eastern-'ulama' books but also ask fatwa immediately to the 'ulama' in order to get the higher authority. ${ }^{8}$ In the case of Forum Komunikasi Ahlus Sunnah wal Jama'ah (FKASWJ), they ask legitimacy for jihad in the Moluccas from six muftis in the Middle East.

Secondly, he talks about the labeling of Islam. For Indonesian Islam, we have 'modernist', 'traditionalist', 'conservative', 'liberal', 'fundamentalist', 'santr', 'abangan', 'real Muslim', 'nominal Muslim'. (p. 231) To him, these labels are inappropriate anymore because the fatâwâ show us a different and more complex Islam. However, these labels are still important as an aid to understand Indonesian Islam using classification.

Thirdly, he talks about Islam as an object. However, he does not explain well about what he means by Islam as an object. Fourthly, he talks about revelation. Is revelation problematic? Answering this question, Hooker argues by showing three arguments. First, readers of fatâwâ will find differences of

${ }^{6}$ Nadirsyah Hosen, Revelation in a Modern Nation State: Mubammadiyah and Islamic Legal Reasoning in Indonesia, 2002, p. 249

${ }^{7}$ Nadirsyah Hosen, NU \& Collective Ijtihad, New Zealand, Journal of Asian Studies 6, 2004, p. 23

${ }^{8}$ Nico Kaptein, The Voice of the Ulama: Fatwas and Religious authority in Indonesia, ISEAS, 2004, p. 15; Noorhaidi Hasan, Between Transnational interest and Domestic Politics: Understanding Middle Eastern Fatwas on Jihad in the Moluccas, Islamic Law and Society 12, 2005, p. 74 
opinion between the sources on quite fundamental matters. It seems that Hooker wants to see one voice of 'ulama' and it is for me impossible. Yes, the revelation is problematic but it is natural when some people have different opinion when they try to understand it. The Revelation itself gives us opportunity to have a different opinion. The second problem is related to authority. Who should have the most authoritative fatâwâ? As far as the five pillars are concerned, the state has successfully established its position in determining times of fast, travel for the pilgrimage, and the capitalization of money. The third aspect of the problematic of Revelation is the scientific/bureaucratic fatâwâ. Can Islam be proved to be true in the scientific sense? The answer from the fatâwa is inferential. It seems to be no, and it is not.

Fifthly, he explains about the fatâwâ which state prescriptions. The fatâwa set out prescription in the areas of clothing, leaving the house, and the capacity of women to exercise authority. The first two raise personal morality and the third raises authority and obedience. However, Hooker sees that identifying a prescription is so problematic. For instance in the case of women going out of the house which is concerned with obedience, motive and necessity. So far as motive is concerned, it can be arranged in a hierarchy. The best motive is to pray but even this is debatable. NU's 1920-1940s fatâwâ did not permit this except in the case of unattractive or old women. Persis always permitted going out to pray with some rules of proper dress. The Muhammadiyah prefers that women pray separately in a mushalla (small Mosque). (p. 240)

Finally, he talks about normative Islam. By quoting Prof. Wael Hallaq's book of legal theory, Hooker defines normative Islam as the five values with which all legal acts must be labeled. They are wâjib, mandîb, mubab $\underline{\text { barâm }}$ and makrûh. However, he concerns more with mubah, makrûh and $\underline{b}$ arâm which as shown by 
the fatâw $\hat{a}$, the boundary of which are permeable throughout the $20^{\text {th }}$ century.

\section{Critical Remarks}

Throughout all chapters, Hooker raises many important and interesting fatâwâ. It is interesting in the sense that some of them are discriminative and gender biased fatâwâ (p. 180) and seem inappropriate at our time. He also smartly elaborates one fatwa with other fatâwa and gives his own view on them although he looks at them from a very secular point of view. However, these are the strength of this book, and further we can learn much from the fatâwa in order to know how Islam is understood in particular time and place, Indonesia.

Here, I would like to sum up my remarks on this book. I have some problems with the way Hooker elaborates the fatâwâ. First, as I have mentioned, he does not arrange the fatâwa in a well order. One fatwa and another fatwa sometimes have no something to do but Hooker tries to relate them. Thus, the theme broadens.

Secondly, in almost all of the fatâwâ, Hooker sees such inconsistencies and eclecticism. He also frequently calls them as doing talfiq which seems negative for him. However, such eclecticism can be very important and positive in order to achieve the public good (maslaba). Therefore, this term is also used by Qodri Azizi as a title of his book and Bustanul Arifin sees it as something proper. ${ }^{9}$ Furthermore, there are many qawailid fiqbiyah which indicate to the changes of laws such as "taghyîr al-abkâm bi-taghayyur al-azminah wa al-amkinah" which means the change of laws lays on the change of times and

${ }^{9}$ Bustanul Arifin says that eclecticism is religious and philosophical system by which one critically selects ideas from various sources and doctrines. See Bustanul Arifin in the prolog of A. Qodri Azizy, Eklektisisme Hukum Nasional; Kompetisis antara Hukum Islam dan Hukum Umum, Gama Media, Yogyakarta, 2002, p. viii 
places; "al-bukm yadûru ma'a 'illatibi wujûdan wa adaman" which means a law is present whenever its ratio legis is present, and it is absent in the absence of its ratio legis. Especially for NU, it has a famous slogan which indicates to the change, "al-mubâfazah 'alâ al-qadìm al-shâlih wa al-akbdz bi al-jadìd al-ashlabl. which means to protect the old which is still good and to take the new which is better.

Thirdly, from Hooker's comments on the fatâwa $\hat{\text {, it seems }}$ that he wishes to see one voice of Indonesian 'ulama'. I think this is impossible. Were Hooker watchfully learning usbul al-figh, he would found that ushûl al-figh provides a wide range of possibility for us to be different in opinion, even al-Qur'an provides the opportunities. ${ }^{10}$ One word can be understood and has many meanings. This is called al-musytarak al-lafzihy. The opportunity of being different can also be found in lafizh 'am/khas, mujmal-mubayyan, muthlaq-muqayyad, and nasikh-mansukh

Fourthly, Hooker does not decide which fatwa from the four sources in a certain case which is the most authoritative and the most accepted by society. This is important to know the Indonesian Islam from the religious dynamics.

FIfthly, even though Hooker limits his study of fatâwa from 1920 to 1990s, he does not mention many religious issues within society in the early 1990s. There are some other issues at that time such as what Islam says about Multi Level Marketing (MLM), the establishment of PT. Syarikat Takaful Indonesia, inter-religious marriage and many others. Perhaps this is because Hooker limits his study on the sources and ignores one person's ideas. However, it is crucial if we want to know how Islam is understood in Indonesia by taking one particular person's opinion into consider.

${ }^{10}$ This may indicate the haphazardness of Hooker on ushul figh. Once, he mentions the definition of mubah as "neither forbidden nor permitted" in the MUI's fatwa on the creation of life. (p. 191) It must be "neither forbidden nor recommended/suggested - it is permitted". 
Finally, the title 'Indonesian Islam' seems to be inappropriate of representing the real Indonesian Islam. Excepted MUI, the three sources formerly, even until recently, could only be found mostly in Java. Therefore, the religious issues which are arisen were Javanese issues. However, this book attractively provokes us to critically learn Indonesian fatâwa and furthermore invites us to predict how the relationship between religious authority and state authority will be in the future.

\section{References}

Bustanul Arifin in the prolog of A. Qodri Azizy, Eklektisisme Hukum Nasional; Kompetisis antara Hukum Islam dan Hukum

Umum, Gama Media, Yogyakarta, 2002 http://www.takaful.com/index.php/profile/list/ Imam Ghazali Said (ed.), Abkam al-Fuqoha, Solusi Problematika Aktual Hukum Islam, Keputusan Muktamar, Munas, dan Konbes Nabdlatul Ulama (1926-1999 M.), Surabaya: LTN NU Jawa Timur, 2005

Nadirsyah Hosen, Fatwas of Majelis Ulama Indonesia, Journal of Islamic Studies 15:2, 2004 NU \& Collective Ijtihad, New Zealand, Journal of Asian Studies 6, 2004 , Revelation in a Modern Nation State: Mubammadiyah and Islamic Legal Reasoning in Indonesia, 2002

Nico Kaptein, The Voice of the Ulama: Fatwas and Religious authority in Indonesia, ISEAS, 2004

Noorhaidi Hasan, Between Transnational interest and Domestic Politics: Understanding Middle Eastern Fatwas on Jihad in the Moluccas, Islamic Law and Society 12, 2005 